\title{
ANALISIS PERBANDINGAN SISTEM INFORMASI PERJALANAN DINAS BERDASARKAN ELEMENTS HUMAN COMPUTER INTERACTION (HCI) (Studi Kasus : Dinas Kesehatan Provinsi Kalimantan Barat)
}

\author{
Ferdian Aditya Pratama ${ }^{1}$, Eko Sediyono ${ }^{2}$ \\ ${ }^{1}$ Mahasiswa, Program Studi S2 Sistem Informasi Universitas Kristen Satya Wacana, Salatiga \\ ${ }^{2}$ Dosen, Program Studi S2 Sistem Informasi Universitas Kristen Satya Wacana, Salatiga \\ Email: ${ }^{1}$ ferdian.aditya2302@gmail.com, ${ }^{2}$ ekosed1 @ yahoo.com
}

(Naskah masuk: 20 Mei 2016, diterima untuk diterbitkan: 20 Juni 2016)

\begin{abstract}
Abstrak
Penggunaan sebuah sistem informasi di dalam sebuah instansi merupakan hal yang wajib untuk dapat memudahkan setiap pekerjaan yang dilakukan di dalamnya. Namun tidak semua sistem informasi yang digunakan dapat memudahkan setiap pekerjaan yang dilakukan. Sistem informasi yang memiliki user interface sulit pastinya akan memperlambat kinerja sebuah instansi. Dinas Kesehatan Provinsi Kalimantan Barat merupakan salah satu organisasi pemerintah yang sudah menerapkan sebuah sistem informasi untuk perjalanan dinas yang terjadi. Sistem informasi perjalanan dinas tersebut telah dikembangkan menjadi dua versi yang berbeda. Namun untuk menguji apakah sistem informasi perjalanan dinas versi 2 sudah menjawab permasalahan pada sistem informasi sebelumnya, maka akan dilakukan perbandingan antara kedua sistem. Sistem informasi perjalanan dinas tersebut akan diuji dengan menggunakan indikator dari elements HCI yaitu usability goal, user's experience, dan user model profile. Tujuan dari penelitian ini adalah membandingkan 2 sistem informasi perjalanan dinas berdasarkan elements $\mathrm{HCI}$ yang digunakan oleh masing-masing sistem informasi usability goal, user's experience, dan target user model profile. Penelitian ini menghasilkan sebuah informasi bahwa sistem informasi perjalanan dinas versi dua sudah berhasil dikembangkan menjadi sebuah sistem informasi yang lebih baik dan lebih mudah digunakan daripada sistem informasi versi sebelumnya.
\end{abstract}

Kata Kunci: Human Computer Interaction, Sistem Informasi, HCI Elements.

\begin{abstract}
The use of an information system in an institution is mandatory in order to facilitate any work done on it. But, not all of an information system can facilitate any work done on it. An information system that has a difficult user interface will slow down the performance of an organization. Provincial Health Office of West Borneo is one of the government's organization which applied an information system for the official duty. The information system was upgraded into two different version. However, to see if the new information system is enough to answer all the requirements, it will be made a comparison between the two system. To compare the system, this research will use an indicator from HCI's element like usability goal, user experience, and user model profile. The purpose of the research is to compare 2 information system for the official duty based on elements of HCI thas was used. The result of this research is an information that the new information system has been successfully developed into a better system and more easier to use instead of the previous version.
\end{abstract}

Keywords: Human Computer Interaction, Information System, HCI Elements

\section{PENDAHULUAN}

Jurnal Teknologi Informasi dan Ilmu Komputer (Pada era perkembangan teknologi, peranan IT merupakan salah satu peran yang paling utama dalam sebuah organisasi yang dapat membantu dalam memanajemenkan sebuah data yang digunakan (Abbasi, Sakrek dan Chiang, 2016). Sistem Informasi merupakan sebuah sistem yang berjalan pada suatu organisasi yang mempertemukan kebutuhan pengolahan transaksi harian, mendukung operasi, bersifat manajerial dan kegiatan strategi dari suatu organisasi dan menyediakan pihak luar tertentu dengan laporan-laporan yang diperlukan (Jogiyanto,
2005). Suatu organisasi yang belum menerapkan sebuah sistem di dalamnya akan mengalami kesulitan dalam melakukan pekerjaannya ataupun melakukan management di dalam organisasi tersebut. Pada era teknologi seperti sekarang ini, banyak instansiinstansi yang menggunakan berbagai macam jenis software untuk membantuk dalam mengerjakan sesuatu. Software itu sendiri layaknya sebuah produk yang diproduksi, memiliki sebuah kualitas tersendiri yang bertujuan untuk membantu sebuah pekerjaan secara optimal (Mejia et al, 2012). Salah satu pentingnya sebuah sistem informasi dalam sebuah organisasi adalah memudahkan pekerjaan yang dilakukan di dalamnya. Pada organisasi Dinas 
Kesehatan Provinsi Kalimantan Barat, salah satu penggunaan sistem informasi diterapkan pada bagian management penugasan pegawai.

Sistem informasi perjalanan dinas versi 1 memiliki beberapa prosedur yang digunakan untuk membuat sebuah surat perjalanan dinas yaitu (1) memilih menu data surat, (2) memilih menu data pegawai, (3) memilih data pegawai, (4) mengisi formulir surat penugasan, (5) menyimpan ke dalam database. Proses tersebut diterapkan ke dalam sistem informasi perjalanan dinas versi 1 yang bertujuan untuk memudahkan proses pembuatan surat perjalanan dinas yang sebelumnya masih dilakukan secara manual. Namun berdasarkan hasil wawancara dengan Kepala Dinas, sistem informasi tersebut masih memiliki beberapa kelemahan di dalam user interface yang digunakan seperti proses pembuatan surat tugas yang memakan banyak prosedur dan sistem navigasi yang digunakan masih terlalu sulit untuk digunakan sehingga mempengaruhi kemudahan sistem untuk dipelajari dan kemudahan sistem untuk diingat penggunaannya.

Sedangkan sistem informasi perjalanan dinas versi 2 dikembangkan untuk menjawab permasalahan yang terjadi pada sistem informasi perjalanan dinas versi sebelumnya. Proses pembuatan surat perjalanan dinas yang terjadi pada sistem informasi perjalanan dinas versi 2 tidak memiliki perbedaan yang signifikan dari sistem informasi sebelumnya yaitu (1) memilih data pegawai (2) mengisi formulir surat penugasan, (3) menyimpan ke dalam database. Namun untuk menguji apakah sistem informasi perjalanan dinas versi 2 sudah menjawab permasalahan pada sistem informasi sebelumnya, maka akan dilakukan perbandingan antara kedua sistem. Ada beberapa indikator yang akan digunakan untuk melakukan perbandingan kedua sistem tersebut ditunjukkan pada Tabel 1.

Tabel 1. Indikator Elements HCI (Majid dkk, 2011)

\begin{tabular}{|c|c|}
\hline HCI Elements & Indikator \\
\hline Usability goal & Efficient to use \\
\hline & Effective to use \\
\hline & Easy to learn \\
\hline & $\begin{array}{c}\text { Easy to remember } \\
\text { how to use }\end{array}$ \\
\hline User's experience & Helpful \\
\hline & Satisfying \\
\hline $\begin{array}{c}\text { User } \\
\text { Profile }\end{array}$ & Friendly \\
\hline
\end{tabular}

Berdasarkan latar belakang yang telah dijabarkan, maka akan dilakukan penelitian mengenai analisis perbandingan sistem informasi perjalanan dinas berdasarkan elements human computer interaction. Tujuan dari penelitian ini adalah membandingkan 2 sistem informasi perjalanan dinas berdasarkan elements HCI yang digunakan oleh masing-masing sistem informasi yaitu usability goal, user's experience, dan target user model profile. Penelitian ini akan menghasilkan sebuah perbandingan mengenai sistem informasi perjalanan dinas yang lebih mudah untuk digunakan.

\section{KAJIAN PUSTAKA}

\subsection{Penelitian Terdahulu}

Penelitian yang dilakukan oleh Majid dkk, telah membahas mengenai pentingnya peranan dari $\mathrm{HCI}$ terhadap sebuah proses SDLC. Penelitian ini juga membahas mengenai elements yang terdapat dalam HCI yaitu usability goals, user experience, dan user model profile. Tujuan dari penelitian ini adalah mengidentifikasikan peranan user di dalam proses SDLC dan mengidentifikasikan elements HCI yang digunakan di dalamnya. Hasil dari penelitian ini mengatakan bahwa peranan user di dalam proses SDLC sangat besar tetapi hanya pada tahapan requirements saja. Selain itu didapatkan bahwa elements dari HCI sendiri sudah diterapkan dengan jelas dalam setiap fase analisis dari proses SDLC (Majid dkk, 2011)

\subsection{Dasar Teori}

Human Computer Interaction (HCI) merupakan sebuah ilmu yang mengarah kegunaan atau manfaat dari suatu software. HCI itu sendiri juga merupakan sebuah ilmu yang digunakan untuk mengetahui kualitas dari suatu hubungan antara manusia dengan teknologi (Nunes, Paula \& Filipe, 2010). Sebuah sistem yang menggunakan HCI di dalamnya haruslah didesain untuk menjadi sebuah sisem yang efektif, efisien, menarik, bisa mengatasi masalah, dan mudah untuk dipelajari (Fallman, 2011). Selain itu, sistem yang digunakan juga harus di desain secara simple dan memiliki sistem navigasi yang mudah untuk dioperasikan (Hasnine dkk, 2015). HCI memiliki 6 aspek yang diperhatikan yaitu usability, understandability, learnability, operability, attractiveness, dan compliance (Majid, Noor \& Wan, 2010). Untuk membangun sebuah sistem informasi yang digunakan untuk keperluan bisnis ataupun personal, HCI merupakan salah satu ilmu yang wajib untuk diperhatikan agar sistem yang dibangun dapat berjalan sesuai dengan kebutuhan user (Shiau, Yan dan Kuo, 2016). HCI merupakan cross-disciplinary area yang bersangkutan dengan teori, desain, implementasi dan evaluasi yang digunakan oleh manusia untuk melakukan interaksi dengan computer (Kim, 2012).

Human computer interaction memiliki beberapa elements di dalamnya yaitu usability goal, dimana elements HCI ini bertujuan untuk mengetahui seberapa efektif dan efisien sebuah sistem terhadap user yang menggunakannya. User's experience, dimana elements HCI ini bertujuan untuk mengetahui seberapa sesuai sistem yang digunakan dengan kebutuhan yang dibutuhkan. User model profile, 
dimana elements HCI ini bertujuan untuk mengetahui seberapa besar user mengenali sistem yang baru berdasarkan pengalaman mereka menggunakan sistem yang lama (Majid \& Noor, 2011).

Sistem informasi adalah suatu sistem buatan manusia yang secara umum terdiri atas sekumpulan komponen berbasis komputer dan manual yang dibuat untuk menghimpun, menyimpan, dan mengelola data serta menyediakan informasi keluaran kepada para pengguna (Kadir, 2014). Pada buku Abdul Kadir mengenai sistem informasi, menyatakan bahwa sistem informasi dapat memberikan nilai tambah terhadap proses, produksi, kualitas, manajemen, pengambilan keputusan dan pemecahan masalah, serta keunggulan kompetitif yang tentu saja sangat berguna bagi kegiatan bisnis.

Sistem informasi perjalanan dinas merupakan sebuah sistem informasi berbasis web yang digunakan oleh Dinas Kesehatan Provinsi Kalimantan Barat. Sistem informasi perjalanan dinas bertujuan untuk membuat sebuah surat perjalanan dinas bagi para pegawai yang ditugaskan. Sistem informasi perjalanan dinas memiliki 3 fungsi utama didalamnya yaitu (1) pembuatan surat perjalanan dinas, (2) mencetak surat perjalanan dinas, (3) melakukan analisa terhadap data surat perjalanan dinas yang dibuat berdasarkan data KaBid (Kepala Bidang), KaSie (Kepala Sie), Nama Staff, Tujuan Penugasan, dan total keberangkatan masing-masing kategori baik per bulan ataupun per tahun.

\section{Metodologi}

Penelitian ini menggunakan elements HCI sebagai indikator utama yang digunakan. Adapun beberapa indikator yang digunakan yairtu usability goals, user's experience, dan user model profile. Sistem informasi yang dibandingkan adalah antara sistem informasi perjalanan dinas versi 1 dengan sistem informasi perjalanan dinas versi 2 yang memiliki prosedur pembuatan surat perjalanan dinas yang sama. Penelitian ini menggunakan metode kuantitatif dimana pada penelitian ini menggunakan hipotesa atau teori dari human computer interaction. Teknik pengumpulan data yang digunakan dalam penelitian ini berupa kuisioner dan wawancara. Jumlah responden yang digunakan dalam penelitian ini yaitu sebanyak 30 responden yang merupakan user yang menggunakan sistem informasi perjalanan dinas berbasis web ini. Penelitian ini menggunakan rumus Cronbach Alpha yang digunakan untuk menguji nilai reabilitas dari kuisioner yang digunakan. Adapun tahapan penelitian yang digunakan di dalam penelitian ini ditunjukkan pada Gambar 1 .

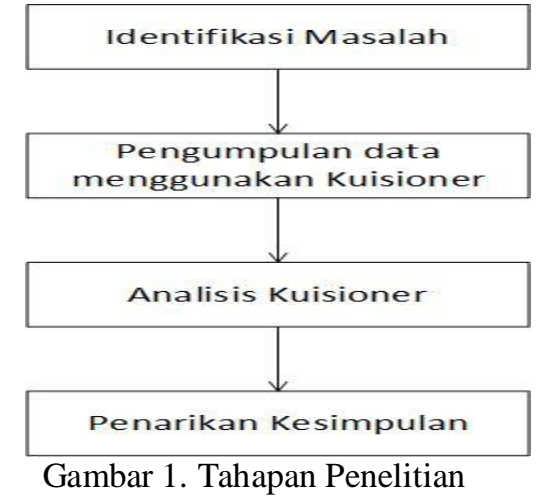

\section{Analisis dan Pembahasan}

Sistem informasi perjalanan dinas memiliki 3 aktor yang dapat menjalankan sistem informasi tersebut. Pada aktor admin / kepala dinas memiliki 1 username, aktor asisten kepala dinas memiliki 1 username, dan aktor staff memiliki 5 username yang digunakan yang dibagi berdasarkan kelompok bidang yang ada pada instansi tersebut. Adapun sistem navigasi yang digunakan oleh kedua versi dari sistem informasi perjalanan dinas dari sisi admin ditunjukkan pada Tabel 2.

TABEL 2

\begin{tabular}{|c|c|}
\hline MENU & FUNGSI \\
\hline Dashboard & - Tampilan awal web. \\
\hline Data Pegawai & $\begin{array}{l}\text { - Menampilkan data } \\
\text { pegawai } \\
\text { - Melakukan update, delete } \\
\text { data pegawai } \\
\text { - Melakukan pembuatan } \\
\text { surat tugas. }\end{array}$ \\
\hline Tambah Pegawai & $\begin{array}{l}\text { - Melakukan insert pegawai } \\
\text { baru }\end{array}$ \\
\hline Data Surat & $\begin{array}{l}\text { - Menampilkan data surat } \\
\text { perjalanan dinas } \\
\text { - Melakukan update, delete } \\
\text { data surat } \\
\text { - Melakukan pencetakan } \\
\text { surat perjalanan dinas }\end{array}$ \\
\hline Grafik & $\begin{array}{l}\text { - Menyediakan tampilan } \\
\text { grafik berdasarkan data } \\
\text { surat perjalanan dinas. }\end{array}$ \\
\hline Laporan Penugasan & $\begin{array}{l}\text { - Menampilkan menu } \\
\text { laporan berdasarkan data } \\
\text { surat perjalanan dinas. }\end{array}$ \\
\hline Logout & $\begin{array}{l}\text { - Keluar dari sistem } \\
\text { informasi perjalanan dinas }\end{array}$ \\
\hline
\end{tabular}

Sistem navigasi yang digunakan oleh kedua versi sistem informasi perjalanan dinas dari sisi asisten admin ditunjukkan pada Tabel 3. 
TABEL 3

MENU SISTEM INFORMASI BESERTA FUNGSINYA ASISTEN ADMIN

\begin{tabular}{|c|c|}
\hline MENU & FUNGSI \\
\hline Data Pegawai & $\begin{array}{l}\text { - Menampilkan data pegawai } \\
\text { - Melakukan update, delete } \\
\text { data pegawai } \\
\text { - Melakukan pembuatan surat } \\
\text { tugas. }\end{array}$ \\
\hline Tambah Pegawai & $\begin{array}{l}\text { - Melakukan insert pegawai } \\
\text { baru }\end{array}$ \\
\hline Data Surat & $\begin{array}{l}\text { - Menampilkan data surat } \\
\text { perjalanan dinas } \\
\text { - Melakukan update, delete } \\
\text { data surat } \\
\text { - Melakukan pencetakan surat } \\
\text { perjalanan dinas }\end{array}$ \\
\hline Logout & $\begin{array}{l}\text { - Keluar dari sistem informasi } \\
\text { perjalanan dinas }\end{array}$ \\
\hline
\end{tabular}

Sedangkan sistem navigasi yang digunakan oleh kedua veris sistem informasi perjalanan dinas dari sisi staff ditunjukkan pada Tabel 4.

TABEL 4

\begin{tabular}{|c|c|}
\hline & 11 A FUNGSINYA \\
\hline MENU & FUNGSI \\
\hline Data Pegawai & $\begin{array}{l}\text { - Menampilkan data } \\
\text { pegawai } \\
\text { - Melakukan update, } \\
\text { delete data pegawai } \\
\text { - Melakukan pembuatan } \\
\text { surat tugas. }\end{array}$ \\
\hline Logout & $\begin{array}{l}\text { - Keluar dari sistem } \\
\text { informasi perjalanan } \\
\text { dinas }\end{array}$ \\
\hline
\end{tabular}

Pengumpulan data pada penelitian ini dilakukan dengan penyebaran kuisioner kepada 30 responden yang mengoperasikan sistem informasi perjalanan dinas. Kuisioner yang digunakan terdiri dari 11 pertanyaan yang dibagi berdasarkan indikator yang digunakan. Kuisioner digunakan untuk mengumpulkan data dari 2 sistem informasi perjalanan dinas dengan menggunakan pertanyaan yang sama untuk masing-masing sistem informasi perjalanan dinas. Kuisioner yang digunakan juga sudah dilakukan uji reabilitiasnya dengan menggunakan Cronbach Alpha dan menghasilkan nilai reabilitas 1 yang menunjukkan bahwa kuisioner yang digunakan memiliki reabilitas yang baik. Adapaun rumus dari Cronbach Alpha ditunjukkan pada Persamaan 1.

$$
=\left[\frac{\mathrm{k}}{(\mathrm{k}-1)}\right]\left[1-\frac{\sum \sigma^{2}}{\sigma^{2}}\right]
$$
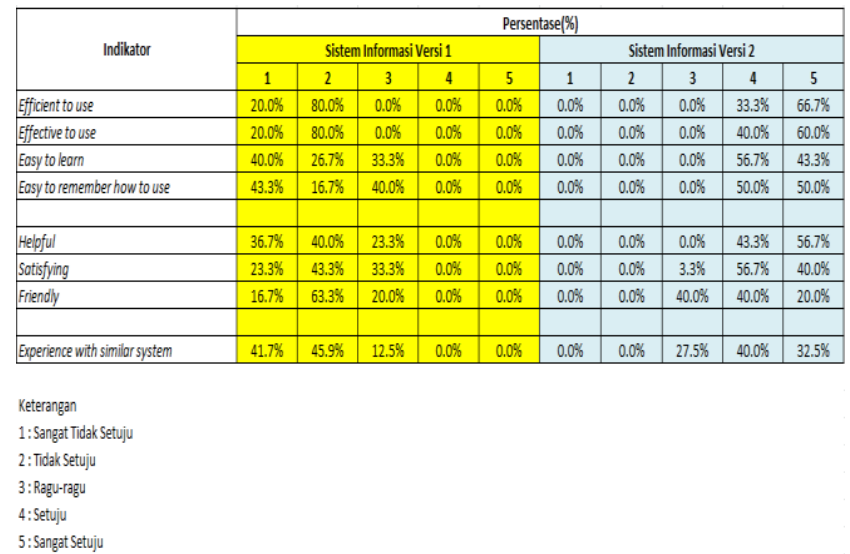

Gambar 2. Persentase Dari Indikator Elements HCI.

Gambar 2 menunjukkan persentase perbandingan dari kedua sistem informasi dengan masing-masing indikator yang digunakan. Berdasarkan hasil dari Gambar 2, didapatkan beberapa hasil bahwa dari element usability goals (1) sistem informasi versi 2 sudah dapat menghemat waktu dalam proses pembuatan surat perjalanan dinas daripada sistem informasi perjalanan dinas versi 1 . (2) Sistem informasi versi 2 sudah menghasilkan sebuah format surat tugas yang dibutuhkan dan memiliki keterangan data penugasan yang lebih lengkap daripada sistem informasi perjalanan dinas versi 1. (3) Sistem informasi perjalanan dinas versi 2 lebih mudah untuk dipelajari dan mudah untuk digunakan daripada sistem informasi versi 1 . Hal ini dikarenakan sistem navigasi yang digunakan pada sistem informasi versi 2 sudah menggunakan menumenu berupa tulisan, sedangkan pada sistem informasi versi 1, menu yang digunakan berupa gambar atau icon.

Untuk indikator user's experience didapatkan beberapa hasil yaitu (1) sistem informasi perjalanan dinas versi 2 sudah lebih membantu dalam proses pembuatan surat perjalanan dinas daripada versi 1 . Hal ini dikarenakan navigasi dari sistem informasi perjalanan dinas versi 2 yang lebih mudah untuk digunakan dan dipelajari daripada versi sebelumnya. (2) Sistem informasi perjalanan dinas versi 2 juga sudah menjawab semua kebutuhan yang diperlukan baik itu dari sisi proses pembuatan surat perjalanan dinas yang lebih mudah dan menghemat waktu maupun dari sisi pengolahan data perjalanan dinas yang lebih lengkap daripada versi sebelumnya. (3) Sistem informasi perjalanan dinas versi 2 juga lebih memiliki user interface yang lebih mudah untuk digunakan daripada sistem informasi versi sebelumnya.

Untuk indikator user model profile didapatkan beberapa sebuah hasil yaitu (1) untuk proses pengalihan sistem, didapatkan bahwa user tidak 1 ) memiliki kesulitan pada saat melakukan migrasi sistem dari sistem informasi versi 1 ke sistem informasi versi 2. Hal ini dikarenakan menu navigasi yang digunakan pada sistem informasi versi 2 lebih bersifat user friendly daripada versi sebelumnya. 
Namun sebaliknya, jika user kembali diminta untuk menggunakan sistem informasi versi 1 kembali, didapatkan bahwa user kembali mengalami kesulitan dalam penggunaan sistem informasi tersebut.

\section{Kesimpulan}

Berdasarkan dari pembahasan yang sudah dilakukan, dapat ditarik kesimpulan bahwa penerapaan sistem informasi perjalanan dinas versi 2 sudah menjawab semua masalah yang terdapat pada sistem informasi perjalanan dinas versi sebelumnya. Kesimpulan tersebut didapatkan berdasarkan dari hasil pengumpulan data yang dilakukan pada Gambar 2. Dari Gambar 2 tersebut dapat disimpulkan bahwa, tidak ada responden yang mengatakan tidak setuju ataupun sangat tidak setuju pada setiap indikator di sistem informasi perjalanan dinas versi 2. Namun tidak ada responden juga yang mengatakan setuju dan sangat setuju pada setiap indikator di sistem informasi perjalanan dinas versi 1 . Hal ini menunjukkan bahwa, sistem informasi perjalanan dinas versi 2 sudah berhasil dikembangkan menjadi sebuah sistem informasi perjalanan dinas yang lebih baik daripada versi sebelumnya dan telah berhasil menjawab permasalahan yang ada pada sistem informasi versi sebelumnya.

\section{Daftar Pustaka}

Abbasi, Ahmed, Suprateek Sarker, and R. H. Chiang. "Big data research in information systems: Toward an inclusive research agenda." Journal of the Association for Information Systems 17.2 (2016): 3.

Fallman, Daniel. "The new good: exploring the potential of philosophy of technology to contribute to human-computer interaction." Proceedings of the SIGCHI Conference on Human Factors in Computing Systems. ACM, 2011.

Hasnine, M. N., Chayon, M. K. H., \& Rahman, M. M. (2015). A Cost Effective Approach to Develop Mid-size Enterprise Software Adopted the Waterfall Model. World Academy of Science, Engineering and Technology, International Journal of Computer, Electrical, Automation, Control and Information Engineering, 9(5), 11401149.

Kadir, Abdul. "Pengenalan Sistem Informasi Edisi Revisi." (2014).

Kim, J. W. (2012). Human Computer Interaction. Ahn graphics.

Majid,Rogayah Abdul., Noor,Nor Laila Md., Adnan,Wan Adilah Wan.2010.A survey on user involvement in software develpoment life cycle from practitioner's perspectives. Computer Science and Convergence Information Technology (ICCIT), pp.240243, 2010.
Majid, Rogayah Abd, Noor, et al. 2011. Users' Frustration and HCI in the Software Development Life Cycle. International Journal Of Information Processing and Management, vol. 2, no. 1

Mejía, Andrés, et al. "Implementing adaptive interfaces: a user model for the development of usability in interactive systems." Proceedings of the CUBE International Information Technology Conference. ACM, 2012.

Nunes, Francisco, Paula Alexandra Silva, and Filipe Abrantes. "Human-computer interaction and the older adult: an example using user research and personas." Proceedings of the 3rd International Conference on PErvasive Technologies Related to Assistive Environments. ACM, 2010.

Shiau,Wen-Lung., Yan,Chang-Ming., Kuo,ChenChao.2016.The Intellectual Structure of Human Computer Interaction Research. Journal of Information Science \& Engineering, vol.32, pp.703-730. 